\title{
Estimating Global Solar Radiation from Empirical Models: An Application
}

\author{
Özgür Ballı1, ${ }^{1 *}$ (1) \\ ${ }^{1}$ Ministry of National Defence (MND), Aeronautical Engineer at 1'st Air Maintenance Factory Directorate (1.HBFM), Eskisehir, Turkey \\ ${ }^{2}$ Eskisehir Osmangazi University, Graduate School of Natural and Applied Sciences, Batı Meselik Campus, Eskisehir, Turkey
}

\begin{abstract}
Many applications and regions of observe require information on solar radiation. Several mathematical models were proposed to forecast worldwide sun radiation in Turkey and different international locations to do this. Some of meteorological information, along with worldwide sun radiation, sunshine period, temperature, air pressure, wind speed, and relative humidity, among January 1, 2011 and December 31, 2014 were measured. These outcomes have been used to create mathematical models to degree the monthly mean daily global solar radiation at the horizontal surface over Eskisehir. The new analytical models have been tested the usage of 9 generally used statistical techniques, along with the relative percentage error $(E)$, the mean percentage error (MPE), the mean absolute percentage error (MAPE), the sum of squares of relative errors (SSRE), the relative standard error (RSE), the mean bias error (MBE), the root mean square error (RMSE), the t-statistic method (t-stat) and coefficient of determination $\left(\mathrm{R}^{2}\right)$. The new version is predicted to advantage all people concerned or interested by the layout and observe of sun strength packages which include sun furnaces, timber drying, stoves, concentrating collectors, indoors illumination, and thermal load reading of buildings, along with sun engineers, architects, agriculturists, hydrologists., photovoltaics, and meteorological forecasting.
\end{abstract}

Keywords: Global solar radiation, empirical models, statistical analysis, Eskisehir city.

\section{INTRODUCTION}

In this period, the increased decline of power supplies, growing power consumption, and lack of ecological values necessitate a direct response. As the maximum important power fuel, sun power has been part of the answer to the world's power problems. Solar radiation information is wanted for the use, preparation, and creation of sun strength plant life as it tells us how a good deal power moves the earth. Owing to the complexity of sun radiation calculations in phrases of preliminary and restore costs, information on sun radiation is handiest to be had in some geographic locations. As a result, sun power modeling strategies have become an increasing number of applicable because the marketplace for sun power software design, overall performance assessment, and enhancement increases [1-2]. For the improvement and operation of the inexperienced power program, excessive high-satisfactory sun radiation information is wanted to reduce monetary risks. To now, the maximum dependable information have come from a combination of information from ground solar measurement stations and information extracted from satellite TV for PC images [3, 4].
For correct evaluation of sun energy capacity, the use of empirical models is vital for the improvement of sun energy generation and the long-time period survival of natural resources [5]. Long-time period worldwide sun radiation records and different meteorological parameters are regularly used to set up mathematical models for month-to-month implies every day worldwide sun at the horizontal surface prediction. The models are categorized into 3 categories: (1) Only function of sunshine duration; (2) Function of sunshine duration as well as relative humidity and ambient temperature; (3) Independent of sunshine duration and function of relative humidity, ambient temperature and its maximum and minimum.

Several empirical models have been suggested to predict the global solar radiation over Turkey and other countries. Khorasanizadeh and Mohammadi [6] used the eleven empirical models to test for prediction of monthly mean daily global solar radiation over six major cities of Iran, named Isfahan, Karaj, Mashhad, Shiraz, Tabriz and Tehran. Yaiche et al. [7] have used the hourly sunshine duration to develop a global solar irradiation map for all types' of the sky. Robaa [8] reviewed and tested the validity of the existing models 
available for computing the monthly average daily global radiation on a horizontal surface over Egypt. Manzano et al. [9] investigated the performance of Angstrom-Prescott linear equation models to estimate the global solar radiation on horizontal surface at daily and monthly mean daily time over Spain. The existing solar radiation models were analyzed with hourly global solar radiation data measured from January 2009 to December 2011 on Jiading Campus, Tongji University by Yao et al. [10]. The results of this study showed that the existing models established in the form of a Gaussian equation were comparatively accurate, followed by models adjusted or modified from the Whillier - Liu \& Jordan models, and the Newell model was of the lowest accuracy.

On the other hand, Mesri [11] showed and evaluated the performance of the most appropriate models used to recover solar components at ground level, via confronting meteorological techniques to selected semi empirical methods. An innovative approach was tested by the numerical simulation. An adaptive neuro-fuzzy inference system (ANFIS) was applied to develop a model for estimation of daily horizontal global solar radiation by Mohammadi et al. [12]. Long-term measured data for Iranian city of Tabass was used to train and test the ANFIS model. The statistical results verified that the ANFIS model provides accurate and reliable predictions.

The artificial neural network (ANN) techniques have been used in diverse applications in control, robotics, pattern recognition, forecasting, medicine, power systems, manufacturing, optimization, signal processing, and social/ psychological sciences. In the last years, neural network methods have been employed for the prediction of global solar radiation both in time and space. Linares-Rodrieguz et al [13] predicted the solar radiation values in locations without ground measurements, by using the reanalysis data as an alternative to the use of satellite imagery. The model was validated in Andalusia (Spain), using measured data for nine years from 83 ground stations spread over the region. The geographical location (latitude, longitude), the day of the year, the daily clear sky global radiation, and the four meteorological variables was used as input data while the daily global solar radiation was the only output of the ANN in this study. Benghanem et al. [14] used the ANN methods models to estimate and model of daily global solar radiation in their study. The available data such as the global irradiation, diffuse irradiation, air temperature and relative humidity available from 1998 to 2002 at the National Renewable Energy Laboratory (NREL) website were used. It was found that the model using sunshine duration and air temperature as inputs, presented the good accurate results since the correlation coefficient is $97.65 \%$. Sahin et al. [15] tested the estimation capacities of ANN techniques to predict monthly-average daily solar radiation over Turkey. According to results of the study, the satellite-based solar radiation map for Turkey was generated. On the other hand, Koca et al.
[16] suggested the ANN model to estimate the solar radiation parameters for seven cities from Mediterranean region of Anatolia in Turkey. The obtained results indicated that the method could be used by researchers or scientists to design high efficiency solar devices. Additionally, the ANN techniques were employed for designing solar systems and predicting solar radiations by Qazi et al. [17]. This study indicated that ANN network gave good accuracy in terms of prediction error of less than 20\%. Therefore, ANN method as compared to other empirical models was capable to deal with many input meteorological parameters, which made it more accurate and reliable.

Spatial variation of incoming radiation is mainly influenced by topographical and atmospheric features whereas latitudinal gradient is almost insignificant. Park et al. [18] investigated the spatial distribution of solar radiation using topographic factor and sunshine duration in South Korea. Hassan et al. [19] suggested the new ambient-temperature-based models for estimating global solar radiation as alternatives to the widely used sunshine-based models owing to the unavailability of sunshine data at all locations around the world. Seventeen new temperature-based models were established, validated and compared with other three models proposed in the literature (the Annandale, Allen and Goodin models) to estimate the monthly average daily global solar radiation on a horizontal surface.

In this study, several empirical correlation models for estimating the monthly average daily global solar radiation on the horizontal surface were developed in connection with the measured solar radiation, sunshine duration and ambient temperature. These models were applied to Eskişehir City of Turkey. The results of empirical models were compared using the statistical evaluation methods as the relative percentage error $(E)$, the mean percentage error $(M P E)$, the mean absolute percentage error (MAPE), the sum of the squares of relative errors (SSRE), the relative standard error (RSE), the mean bias error (MBE), the root square error (RMSE), and correlation coefficient $\left(R^{2}\right)$.

\section{DATA AND METHODOLOGY}

\subsection{Data set}

The data set of the solar radiation, the wind velocity, the wind direction, the ambient temperature and pressure, and the relative humidity were measured by the measuring station at Eskişehir City of Turkey. The measuring data had been collected between 01 January 2011 and 31 December 2014. The latitude, the longitude, and the elevation of measuring station location is $39^{\circ} 44^{\prime} 49^{\prime \prime}-\mathrm{N}, 30^{\circ} 28^{\prime} 49^{\prime \prime}-\mathrm{E}$, and 853 meters, respectively. The photographs of the measuring station [20] are illustrated in Fig.1 and Fig.2.

\subsection{Astronomical parameters}

\subsubsection{Declination angle $(\delta)$}

The angle between the earth-sun line and the equatorial 


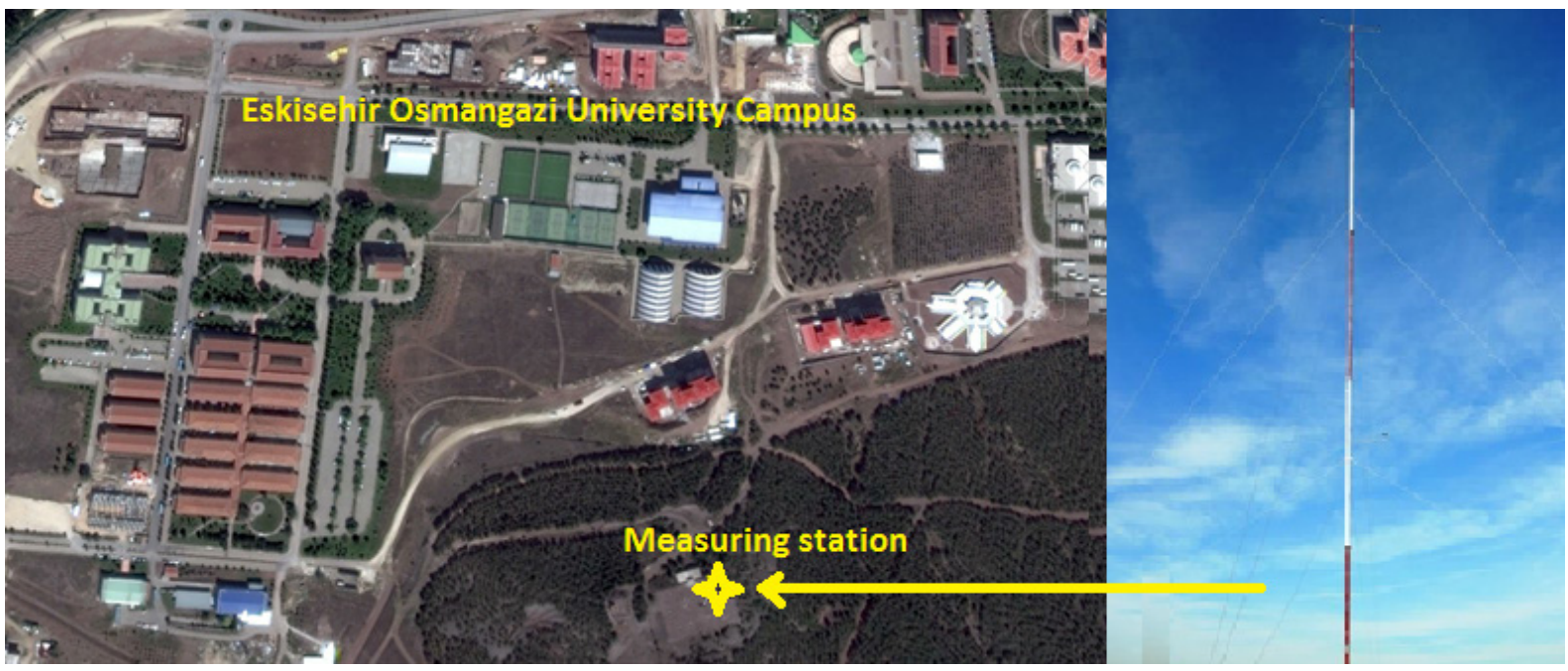

Figure 1. The measuring station at Eskisehir of Turkey [20].

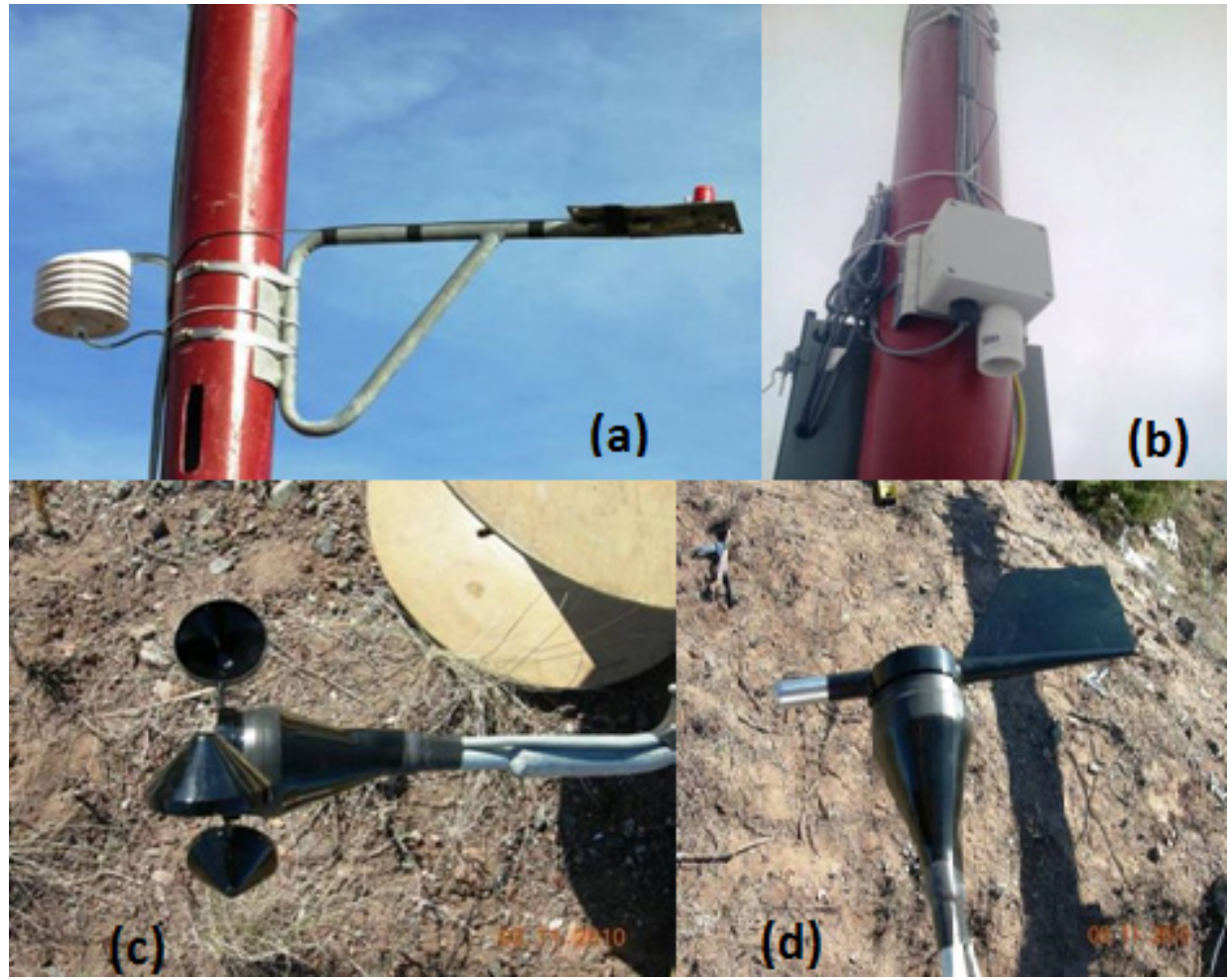

Figure 2. Measurement system parts (a) 110S Temperature sensor with radiation shield for temperature measurement and Li-Cor Li-200R Pyrometer for solar radiation measurement. (b) relative humidity sensor (c) RNRG 40 Anemometer for wind velocity measurement . (d) RNRG 200P Wind vane for wind direction measurement [20].

plane is named the declination angle. It varies over the year from $-23.45^{\circ}$ at the winter solstice to $+23.45^{\circ}$ at summer solstice. The declination angle can ve estimated the following equation [21-24];

$$
\delta=23.45 \sin \left(\frac{360}{365}\left(284+n_{d a y}\right)\right)
$$

where $\mathrm{n}_{\text {day }}$ is the number of the day corresponding to a given date starting from 1 on 1 January to 365 on 31 December.

\subsubsection{Sunset hour angle $\left(w_{s}\right)$}

The sunset hour angle in degrees can be calculated from [21-24];

$$
\omega_{s}=\cos ^{-1}(-\tan \phi \tan \delta)
$$

\subsubsection{Number of daylight hours (daylight duration)}

The number of daylight hours (daylight duration) is based on the hour angle and obtained the following equation [21-24];

$$
S_{o}=\frac{2}{15} \omega_{s}
$$

\subsubsection{Extraterrestrial radiation $\left(G_{o}\right)$}

The amount of solar energy that would be received in the absence of the atmosphere is called the extraterrestrial radiation. The change in the extraterrestrial radiation is caused by two sources, i.e., variation in radiation emitted by the sun and variation of earth-sun distance. This change is considered taking into account the astronomical factors according to the following relation [21, 23-24]; 


$$
G_{o n}=G_{s c}\left(1+0.034 \cos \left(\frac{360 . n_{d w}}{365.25}\right)\right)
$$

The monthly average daily extraterrestrial radiation on a horizontal surface $\left(H_{o}\right)$ was obtained from the following equations $[8,21-24]$,

$$
H_{o}=\frac{24}{\pi} G_{o n}\left(\cos \phi \cos \delta \cdot \sin \omega_{s}+\frac{\pi}{180} \omega_{s} \cdot \sin \phi \cdot \sin \delta\right)
$$

\subsection{Global solar radiation models}

The most well-known models, Angström-Prescott model, express the monthly average daily global solar radiation as a function of the monthly average daily measure sunshine duration as the following [25-26];

$$
\frac{H}{H_{o}} \approx f\left(\frac{S}{S_{o}}\right)
$$

where $H$ is the monthly average daily global solar radiation $\left(M J m^{-2}\right), H_{o}$ is the monthly average daily extraterrestrial radiation $\left(M \mathrm{Mm}^{-2}\right), S$ is the monthly average daily measured sunshine duration $(h)$ and $S_{o}$ is the monthly average daily daylight duration $(h)$.

The first mathematical expression of this type was the linear regression equation developed by Angstrom and modified by Page, and was between the global solar radiation and the sunshine duration, which is the most convenient and widely used as given by [27]:

$$
\frac{H}{H_{o}}=a+b \frac{S}{S_{o}}
$$

In the course of time, the nonlinear polynomial relation models derived from Angstrom linear regression equation were suggested for increasing the accuracy of models at extreme points $[22,28]$. After that, many researchers have done a large number of modifications on this model to improve accuracy. Several typical models based on sunshine duration are given below [18, 29-36],

$$
\begin{aligned}
& \frac{H}{H_{o}}=a+b \frac{S}{S_{o}}+c\left(\frac{S}{S_{o}}\right)^{2} \\
& \frac{H}{H_{o}}=a+b \frac{S}{S_{o}}+c\left(\frac{S}{S_{o}}\right)^{2}+d\left(\frac{S}{S_{o}}\right)^{3} \\
& \frac{H}{H_{o}}=a+b \log \left(\frac{S}{S_{o}}\right) \\
& \frac{H}{H_{o}}=a+b\left(\frac{S}{S_{o}}\right)+c \log \left(\frac{S}{S_{o}}\right) \\
& \frac{H}{H_{o}}=a+\exp \left(\frac{S}{S_{o}}\right) \\
& \frac{H}{H_{o}}=a+b\left(\frac{S}{S_{o}}\right)+c \exp \left(\frac{S}{S_{o}}\right) \\
& \frac{H}{H_{o}}=a+b\left(\frac{S}{S_{o}}\right)^{c} \\
& \frac{H}{H_{o}}=a+b \cos \left(c \frac{S}{S_{o}}\right)+d \sin \left(c \frac{S}{S_{o}}\right)+e \cos \left(2 c \frac{S}{S_{o}}\right)+f \sin \left(2 c \frac{S}{S_{o}}\right)
\end{aligned}
$$

where $a, b, c, d, e, f$ are the correlation coefficients.

The strong relation between solar radiation and ambient temperature can be explained by the behavior of the earth's surface towards the radiation received from the sun. The solar energy that reaches the atmosphere in the form of shortwave electromagnetic radiation is absorbed by the earth's surface, causing the earth to warm up. The warm earth's surface reemits a part of the absorbed energy in the form of long wave radiation to heat up the surrounding ambient air. The ambient air is not directly heated by the solar radiation but is heated by the contact with the hot earth's surface. In general, the fluctuation in air temperature can be affected by radiation balance and air mass advection. The local ambient air temperature and radiation balance are affected by cloud cover and the nature of surface coverage as well as the time of day and day of the year. The systematic variation in incoming solar radiation over the course of a year can be reflected in the annual temperature cycle in which a strong relation between solar radiation and ambient temperature is noticed [36]. Several typical models based on ambient temperature from are given as following [19, 29, 37-41] ;

$$
\begin{aligned}
& \frac{H}{H_{o}}=a+b T \\
& \frac{H}{H_{o}}=a+b T+c T^{2} \\
& \frac{H}{H_{o}}=a+b T+c T^{2}+c T^{3} \\
& H=a+\exp \left(b T^{c}\right)
\end{aligned}
$$

$\frac{H}{H_{o}}=a+b T+c T^{2}+c T^{3}$

$\frac{H}{H_{o}}=a \Delta T^{b}+c$

$\frac{H}{H_{o}}=a T^{b} H_{o}$

$\frac{H}{H_{o}}=a T^{b} H_{o}+c$

$\frac{H}{H_{o}}=(a+b \Delta T) \Delta T^{c}$

$\frac{H}{H_{o}}=\left(a+b \Delta T+c \Delta T^{2}\right) \Delta T^{d}$

$\frac{H}{H_{o}}=\left(a+b \Delta T+c \Delta T^{2}\right) \Delta T^{0.5}+d$

$\frac{H}{H_{o}}=\left(a+b \Delta T+c \Delta T^{2}\right) \Delta T^{d}+e$

$\frac{H}{H_{o}}=\left(a+b \Delta T+c \Delta T^{2}+d \Delta T^{3}\right) \Delta T^{e}+f$

$\frac{H}{H_{o}}=(a+b T) \Delta T^{c}+d$

$\frac{H}{H_{o}}=(a+b T) \Delta T^{c}$

$\frac{H}{H_{o}}=\left(a+b T+c T^{2}\right) \Delta T^{d}+e$

$\frac{H}{H_{o}}=\left(a+b T+c T^{2}\right) \Delta T^{d}$

$\frac{H}{H_{o}}=\left(a+b T+c T^{2}+d T^{3}\right) \Delta T^{e}$ 


$$
\begin{aligned}
& \frac{H}{H_{o}}=a\left(1+2.7 \times 10^{-5} Z\right) \Delta T^{0.5} \\
& \frac{H}{H_{o}}=a\left(1-\exp \left[-b \frac{\Delta T^{c}}{H_{o}}\right]\right)
\end{aligned}
$$

where $\mathrm{Z}$ is the elevation of site from the sea level.

While the solar radiation $(H)$, sunshine duration $(S)$ and the ambient temperature $(T)$ are measured by the measuring station, the daylight duration $\left(S_{o}\right)$ and the extraterrestrial radiation $\left(H_{o}\right)$ are calculated from the eqn. (3) and (eqn. (5), respectively.

\section{STATISTICAL ANALYSIS METHODS}

A number of statistical analysis methods have been used to evaluate the accuracy of the models of solar radiation estimations. Some of these, the relative percentage error $(E)$, the mean percentage error ( $M P E)$, the mean absolute percentage error $(M A P E)$, the sum of the squares of relative errors (SSRE), the relative standard error (RSE), the mean bias error $(M B E)$, the root square error (RMSE), and correlation coefficient $\left(R^{2}\right)$ are the most commonly used to compare the results $[5,8-10,18,22,28,42-45]$. In all the above statistical tests of accuracy, except $R^{2}$, the smaller the value, the better is the model performance. The statistical performance metrics are given in Table 1.

\section{RESULTS AND DISCUSSION}

The monthly average daily values of the global solar radiation $(H)$, sunshine duration $(S)$, wind velocity $(V)$, ambient temperature $(T)$, ambient pressure $(P)$, relative humidity $(R H)$, the extraterrestrial radiation $\left(H_{o}\right)$, daylight duration $\left(S_{o}\right)$, solar radiation fraction $\left(\frac{H}{H_{o}}\right)$ and sunshine duration fraction $\left(\frac{S}{S_{0}}\right)$ were calculated from the 10-secondly measuring data and given in Table 2 . The monthly average daily values of the solar radiation and the sunshine duration were illustrated in Fig. 3 and Fig.4. Using the data in Table 1 and Minitab ${ }^{\mathrm{TM}}$ program; the variations between $\left(\frac{H}{H_{o}}\right)$ and $\left(\frac{S}{S_{o}}\right)$, between $\left(\frac{H}{H_{o}}\right)$ and $(T)$, between $\left(\frac{H}{H_{0}}\right)$ and $(V)$, between $\left(\frac{H}{H}\right)$ and $(R H)$, and between $\left(\frac{H}{H_{o}}\right)$ and $(P)$ were analyzed and indicated in Fig.5. Minitab ${ }^{\mathrm{TM}}$ is a statistical package that provides

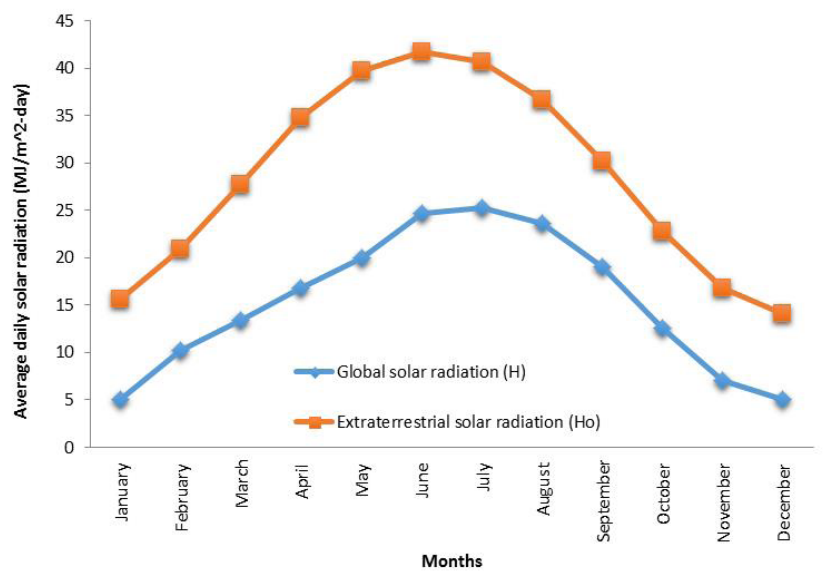

Figure 3. The annually distributions of the monthly average daily global and extraterrestrial solar radiations a broad range of basic and advanced data analysis techniques. It includes regression techniques, analysis of variance experimental design and control charts, quality tools, survival analysis, multivariate analyses, time series, descriptive and non-parametric statistics exploratory data analysis, power and sample-size calculation. The results of analysis, the sunshine duration fraction $\left(\frac{S}{S_{o}}\right)$ and the ambient temperature $(T)$ were determined to be more impressive on the solar radiation fraction $\left(\frac{H}{H_{o}}\right)$. After that, the new twelve empirical models relating to $H, \frac{H}{H_{0}}, \frac{S}{S}$, and $T$ were suggested as fitted to experimental data. The regression graphs, the correlation coefficients $(a, b, c, d, \ldots .$.$) and coefficient of determi-$ nation $\left(R^{2}\right)$ obtained from Minitab ${ }^{\mathrm{TM}}$ were demonstrated in Fig.6-17. The obtained equations for new models are given as the following;

\section{Model-1:}

$$
\frac{H}{H_{o}}=0.1761+0.6021 \frac{S}{S_{o}}, \quad\left(R^{2}=0.935\right)
$$

Model-2:

$$
\frac{H}{H_{o}}=0.1640+0.6529 \frac{S}{S_{o}}-0.0482\left(\frac{S}{S_{o}}\right)^{2}, \quad\left(R^{2}=0.935\right)
$$

\section{Model-3:}

$$
\frac{H}{H_{o}}=0.0315+1.528 \frac{S}{S_{o}}-1.835\left(\frac{S}{S_{o}}\right)^{2}+1.144\left(\frac{S}{S_{o}}\right)^{3}, \quad\left(R^{2}=0.936\right)
$$

Model-4:

$$
\frac{H}{H_{o}}=0.3721+0.01178 T,\left(R^{2}=0.814\right)
$$

Model-5:

$$
\frac{H}{H_{o}}=0.3620+0.01478 T-0.000128 T^{2}, \quad\left(R^{2}=0.817\right)
$$

\section{Model-6:}

$\frac{H}{H_{o}}=0.3364+0.02911 T-0.001668 T^{2}+0.000043 T^{3}, \quad\left(R^{2}=0.827\right)$

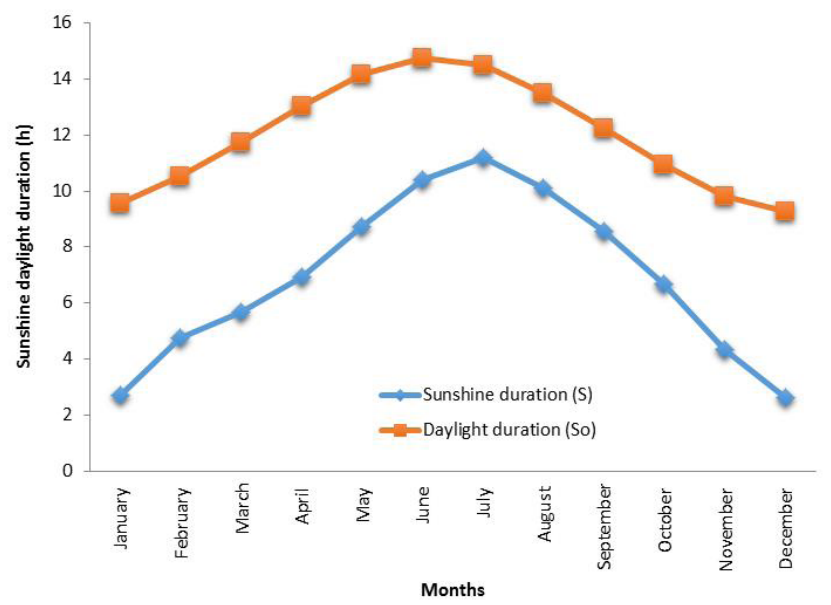

Figure 4. The annually distributions of the monthly average daily sunshine duration and daylight duration. 
Table 1. The performance tools for statistical analysis

\begin{tabular}{|c|c|c|c|}
\hline Metrics & Relations & Explanation & $\begin{array}{l}\text { Eqn. } \\
\text { No. }\end{array}$ \\
\hline $\begin{array}{l}\text { Relative percentage } \\
\quad \text { error }(E)\end{array}$ & $E=\left(\frac{c_{i}-m_{i}}{m_{i}}\right) 100$ & $\begin{array}{l}\text { The } E \text { provides the percentage deviation data between } \\
\text { the calculated and measured. The ideal value of } E \text { equals } \\
\text { to zero. here } c_{i} \text { is the ith calculated value, } m_{i} \text { is the ith } \\
\text { measured value }\end{array}$ & (36) \\
\hline $\begin{array}{l}\text { Mean percentage } \\
\text { error } \\
\text { (MPE) }\end{array}$ & $=\frac{\sum_{i=1}^{n} E}{n}$ & $\begin{array}{l}\text { The mean percentage error is explained as the average } \\
\text { value of percentage deviation between estimated and } \\
\text { measured solar radiations. Where } n \text { is the number of } \\
\text { measured and estimated values }\end{array}$ & (37) \\
\hline $\begin{array}{l}\text { Mean absolute } \\
\text { percentage error } \\
\text { (MAPE) }\end{array}$ & $M A P E=A B S\left(\frac{\sum_{i=1}^{n} E}{n}\right)$ & $\begin{array}{l}\text { The mean absolute percentage error is expressed as the } \\
\text { absolute average value of percentage deviation between } \\
\text { estimated and measured solar radiations }\end{array}$ & (38) \\
\hline $\begin{array}{l}\text { Sum of the squares } \\
\text { of relative error } \\
\text { (SSRE) }\end{array}$ & $\operatorname{SSRE}=\sum_{i=1}^{n}\left(\frac{c_{i}-m_{i}}{m_{i}}\right)^{2}$ & $\begin{array}{l}\text { The SSRE give us the positive value of sum of squares of } \\
\text { relative deviations throughout the year. The ideal value of } \\
\text { SSRE equals to zero. }\end{array}$ & (39) \\
\hline $\begin{array}{l}\text { Relative standard } \\
\quad \text { error (RSE) }\end{array}$ & $=\sqrt{\frac{S S R E}{n}}$ & $\begin{array}{l}\text { The RSE provides the degree of accuracy of estimation } \\
\text { correlations. }\end{array}$ & (40) \\
\hline $\begin{array}{l}\text { Mean bias error } \\
\quad(M B E)\end{array}$ & $\frac{1}{n} \sum_{i=1}^{n}($ & $\begin{array}{l}\text { The mean bias error is the average difference between } \\
\text { measured and estimated values. The } M B E \text { gives some } \\
\text { information on the long-term performance of correlati- } \\
\text { ons. The positive } M B E \text { indicates an overestimation, while a } \\
\text { negative } M B E \text { shows an underestimation. The ideal value } \\
\text { of } M B E \text { is zero. }\end{array}$ & (41) \\
\hline $\begin{array}{l}\text { Root mean square } \\
\text { error (RMSE) }\end{array}$ & $\sqrt{\frac{1}{n} \sum_{i=1}^{n}\left(c_{i}-m_{i}\right)^{2}}$ & $\begin{array}{l}\text { The RMSE provides a general indicator about on the } \\
\text { short-term performance of correlations. The RMSE is } \\
\text { always positive. Because the lower of RMSE values shows } \\
\text { the more accurate model, the ideal value of RMSE equals } \\
\text { to zero and is always positive }\end{array}$ & (42) \\
\hline \multirow{2}{*}{$\begin{array}{l}\text { Correlation coeffi- } \\
\quad \text { cient }\left(R^{2}\right)\end{array}$} & $R^{2}=\frac{\sum_{i=1}^{n}\left(c_{i}-c_{a}\right)\left(m_{i}-m_{a}\right)}{}$ & \multirow{2}{*}{$\begin{array}{l}\text { The correlation coefficient is used to analyze for deter- } \\
\text { mining the relation between estimated and measured } \\
\text { values. Where } c_{a} \text { and } m_{a} \text { expressed the average of the } \\
\text { calculated and measured values, respectively. }\end{array}$} & \multirow{2}{*}{ (43) } \\
\hline & $\sqrt{\left[\sum_{i=1}^{n}\left(c_{i}-c_{a}\right)^{2}\right]\left[\sum_{i=1}^{n}\left(m_{i}-m_{a}\right)^{2}\right]}$ & & \\
\hline $\begin{array}{l}\text { t-statistic method } \\
\quad(t \text {-stat })\end{array}$ & $t-s t a t=\sqrt{\left[\frac{(n-1) M B E^{2}}{R M S E^{2}-M B E^{2}}\right]}$ & $\begin{array}{c}\text { To determine whether or not the equation estimates are } \\
\text { statistically significant, i.e., not significantly different from } \\
\text { their actual counterparts, at a particular confidence level, } \\
\text { it is proposed the t-statistic as the correlation. }\end{array}$ & (44) \\
\hline
\end{tabular}

Model-7:

$$
H=-1.981+2.496 S,\left(R^{2}=0.979\right)
$$

\section{Model-8:}

$$
H=-1.717+2.402 S+0.00683 S^{2},\left(R^{2}=0.979\right)
$$

\section{Model-9:}

$$
H=2.086+0.238 S+0.3616 S^{2}-0.01744 S^{3},\left(R^{2}=0.98\right)
$$

Model-10:

$$
H=4.959+0.8847 T,\left(R^{2}=0.910\right)
$$

Model-11:

$$
H=5.018+0.8669 T+0.00076 T^{2},\left(R^{2}=0.910\right)
$$

\section{Model-12:}

$$
H=54.617+1.091 T-0.0234 T^{2}+0.00068 T^{3},\left(R^{2}=0.910\right)
$$

The measured and estimated values of $H$ were given in Table 3 and shown in Fig.18-21. By using the statistical analysis methods, the values of $H$ in Table 3 estimated from new models were compared with the measured values and tabulated in Table 4. The main remarkable statistical results are given as the following;

(i) Between the new models, Model 1(eqn.(45)) has the best MAPE value with 4.52 between the new models.

(ii) Model-3 (eqn.(47)) has the best MPE, SSRE, RSE, RMSE and $\mathrm{R}^{2}$ values with $0.22, \mathrm{SSRE}=$ $0.00257, \mathrm{RSE}=0.01463, \mathrm{RMSE}=0.77312$ and 0.99457 .

(iii) Model-11 has the best MBE and t-stat values with 0.00022 and 0.00034 between the new models. 


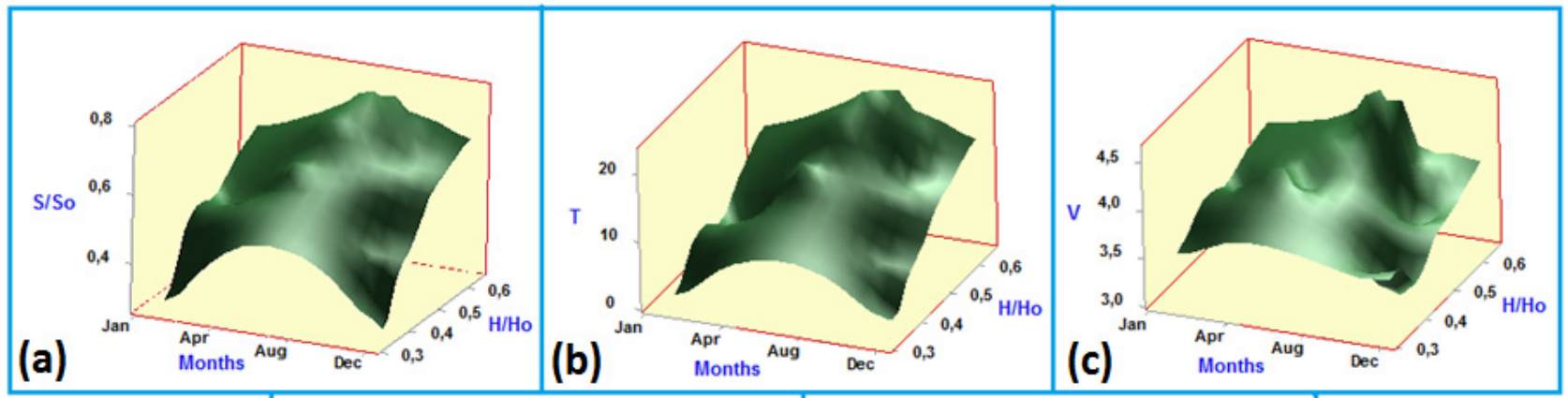

(a)

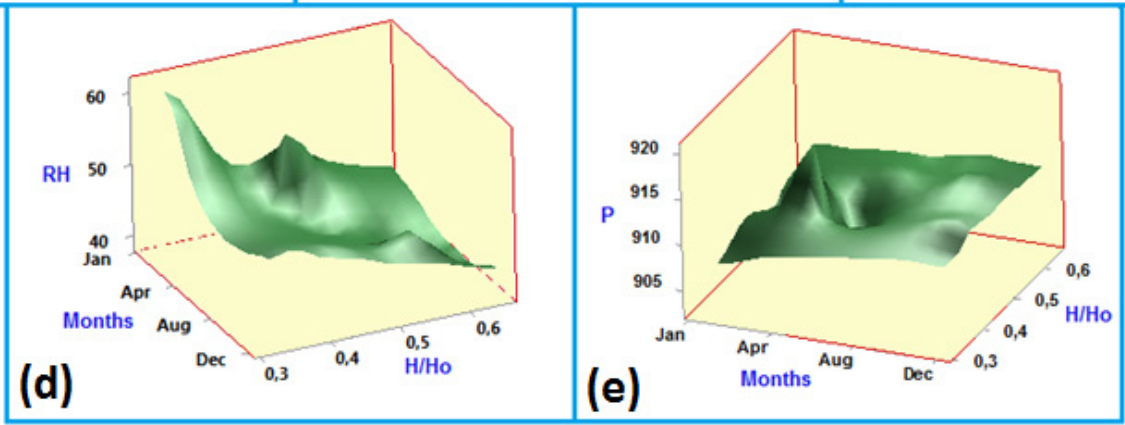

Figure 5. The variations (a) between $\left(\frac{H}{H_{*}}\right)$ and $\left(\frac{S}{S_{s}}\right)$, (b) between $\left(\frac{H}{H_{0}}\right)$ and $(T),(\mathrm{c})$ between $\left(\frac{H}{H_{0}}\right)$ and $(\mathrm{V}),(\mathrm{d})$ between $\left(\frac{H}{H_{\mathrm{o}}}\right)$ and $(R H),(\mathrm{e})$ between $\left(\frac{H}{H_{\mathrm{o}}}\right)$ and $(P)$.

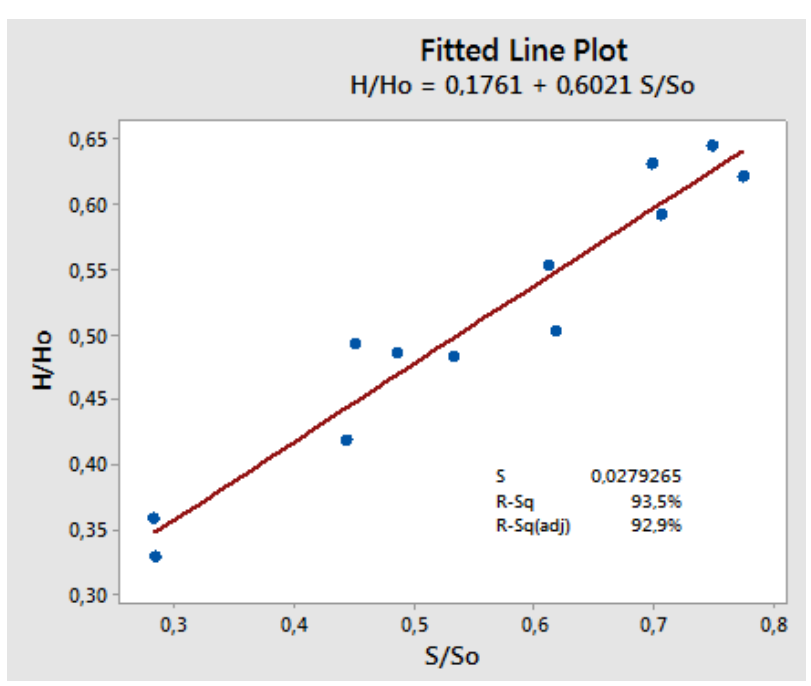

Figure 6. Linear regression between $\left(\frac{H}{H_{0}}\right)$ and $\left(\frac{S}{S_{o}}\right)$

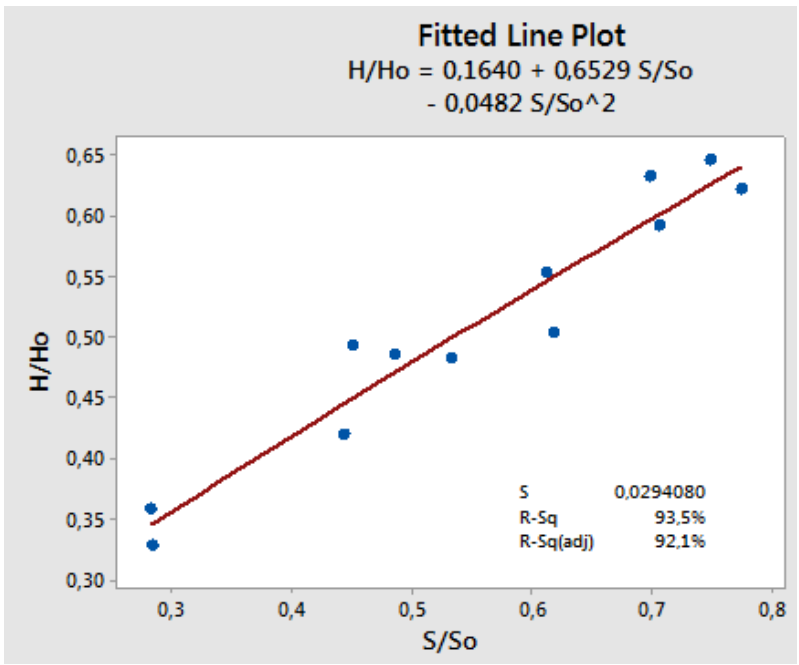

Figure 7. Second order polynomial regression line between $\left(\frac{H}{H_{o}}\right)$ and $\left(\frac{S}{S_{o}}\right)$

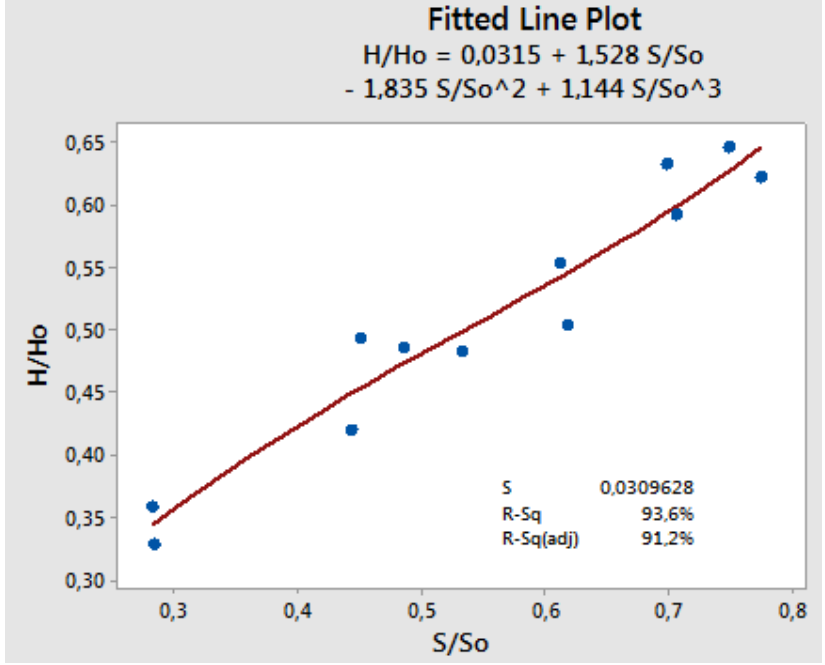

Figure 8. Third order polynomial regression line between $\left(\frac{H}{H_{o}}\right)$ and $\left(\frac{S}{s_{s}}\right)$

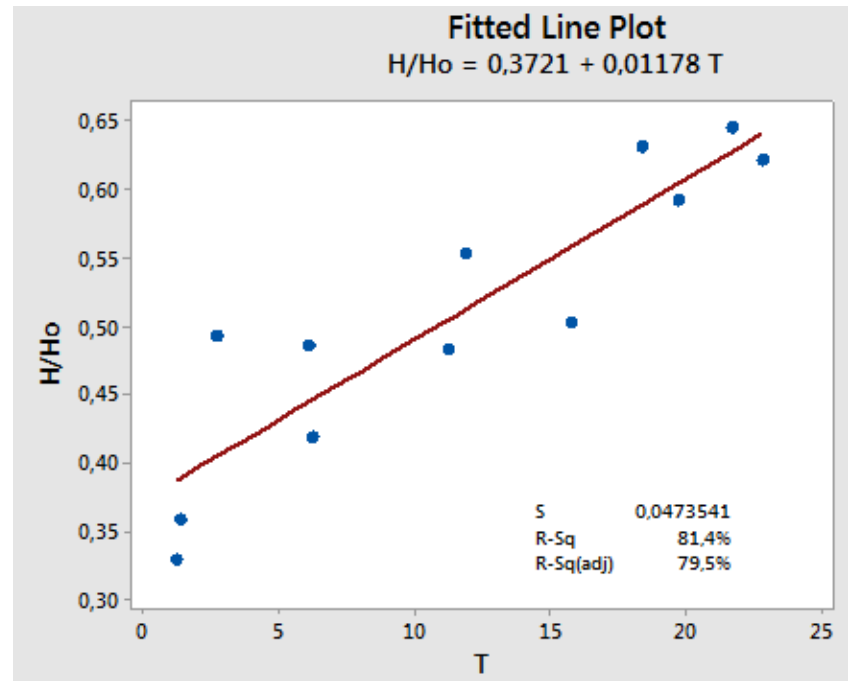

Figure 9. Linear regression between $\left(\frac{H}{H_{o}}\right)$ and $(T)$ 


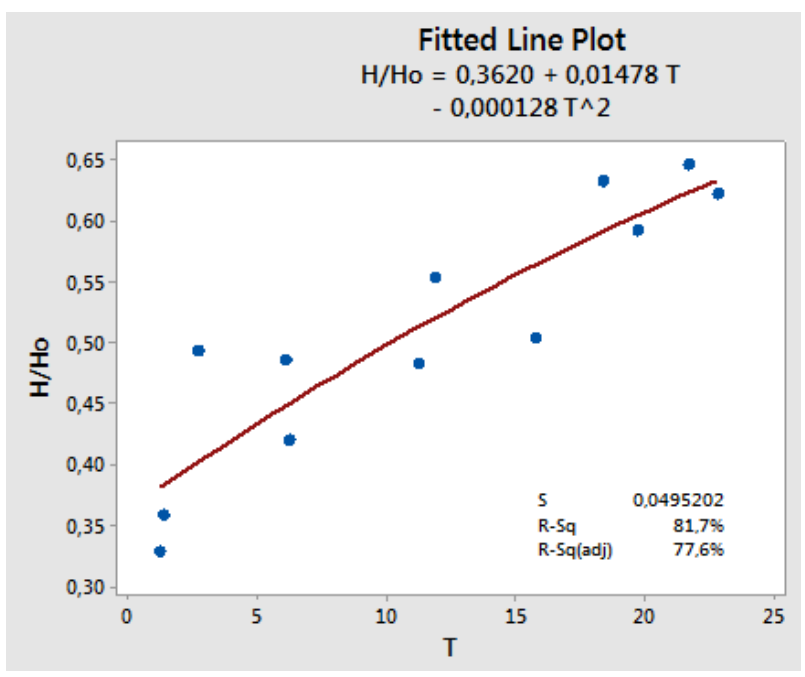

Figure 10. Second order polynomial regression line between $\left(\frac{H}{H_{o}}\right)$ and $(T)$

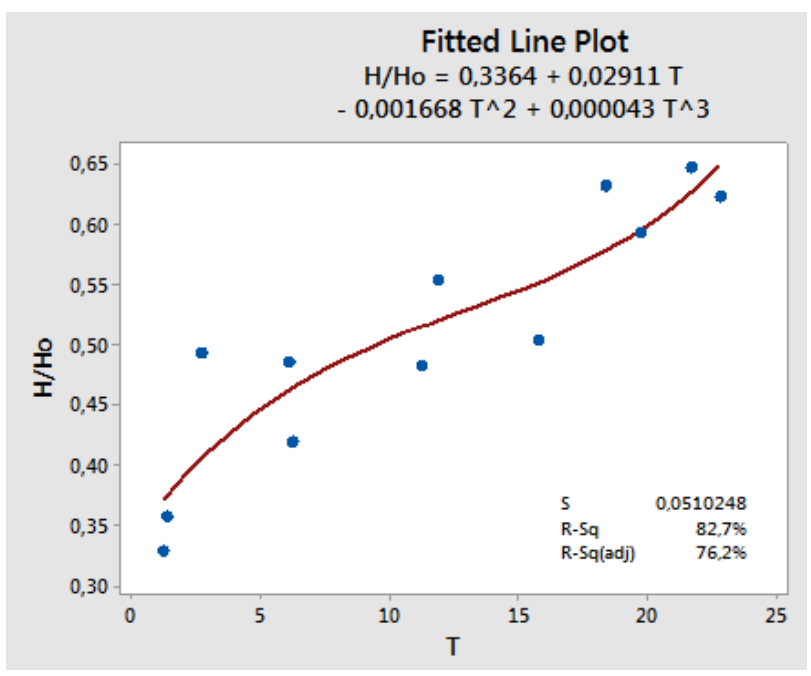

Figure 11. Third order polynomial regression line between $\left(\frac{H}{H_{\mathrm{o}}}\right)$ and $(T)$

Fitted Line Plot $\mathrm{H}=-1,981+2,496 \mathrm{~S}$

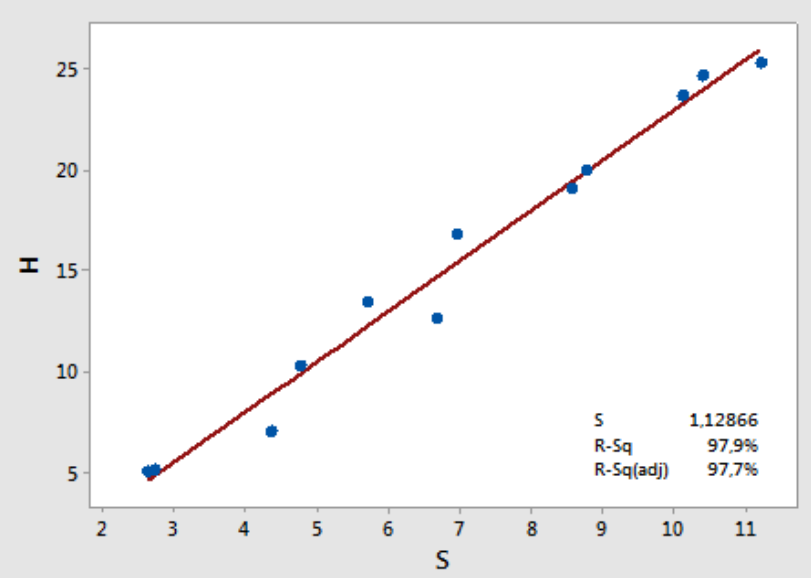

Figure 12. Linear regression between ${ }^{(H)}$ and $(S)$

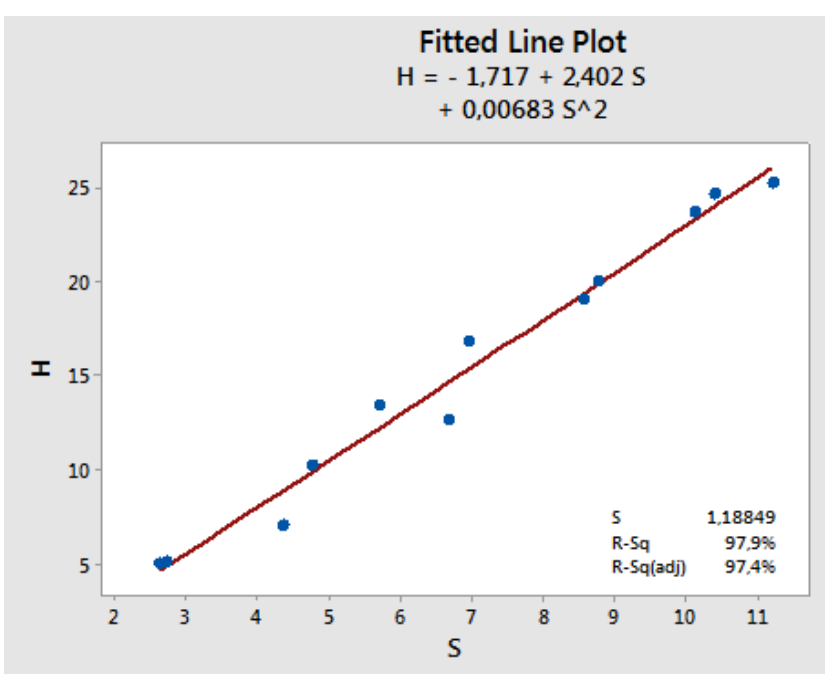

Figure 13. Second order polynomial regression line between ${ }^{(H)}$ and $(S)$

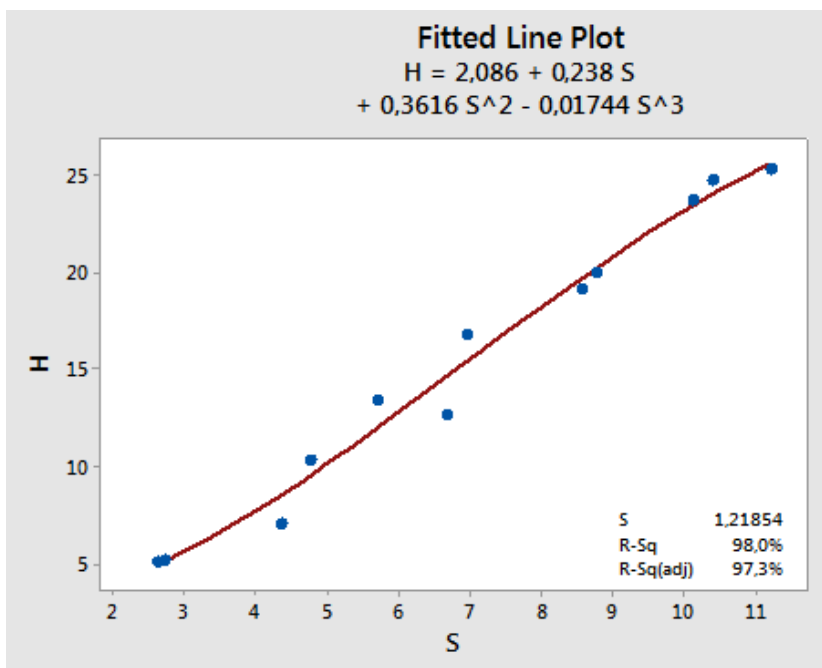

Figure 14. Third order polynomial regression line between ${ }^{(H)}$ and $(S)$

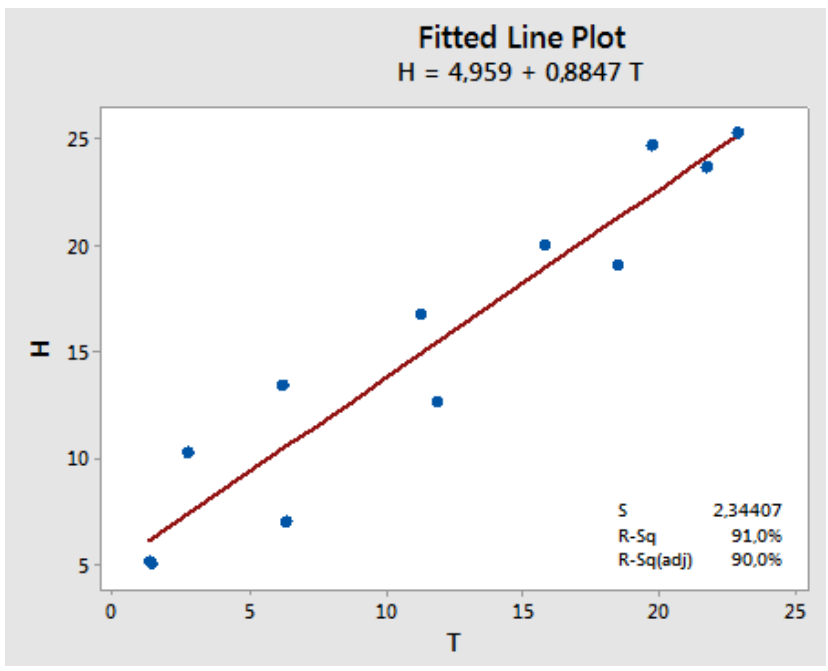

Figure 15. Linear regression between ${ }^{(H)}$ and ${ }^{(T)}$ 


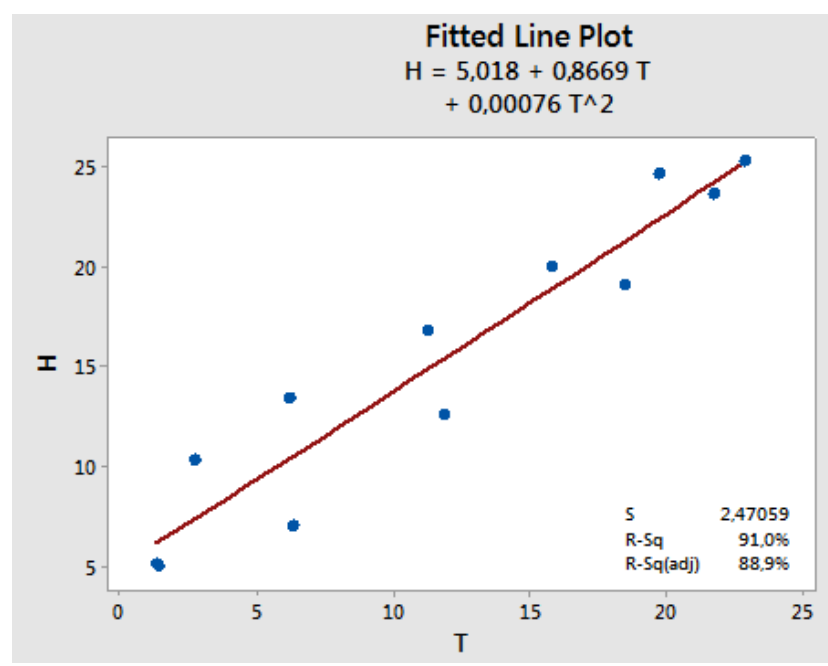

Figure 16. Second order polynomial regression line between ${ }^{(H)}$ and ${ }^{(T)}$

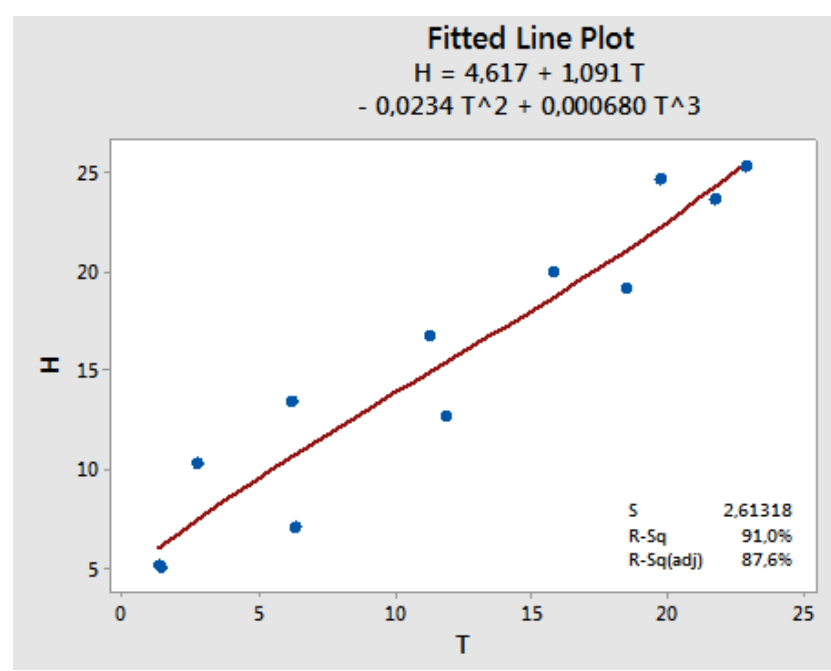

Figure 17. Third order polynomial regression line between ${ }^{(H)}$ and ${ }^{(T)}$

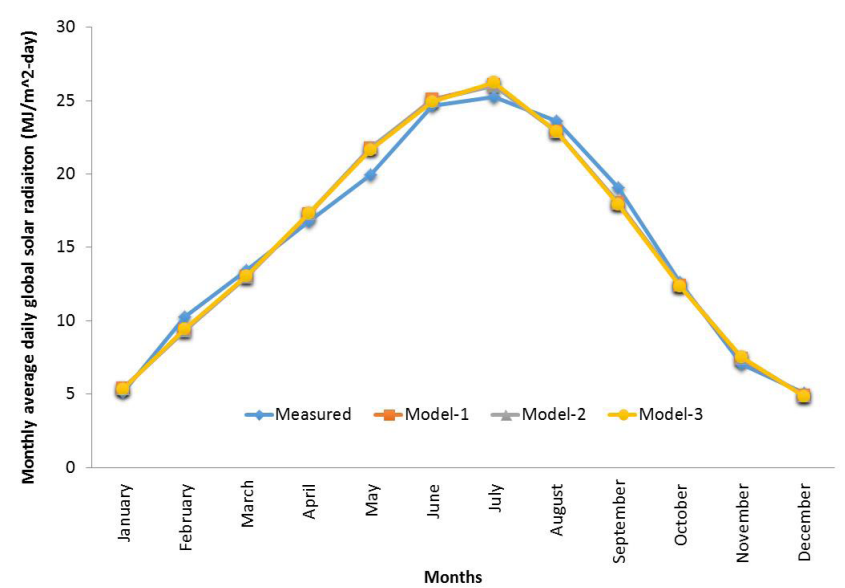

Figure 18 . The annually distributions of the monthly average daily solar radiation estimated from Model-1, Model-2 and Model-3.

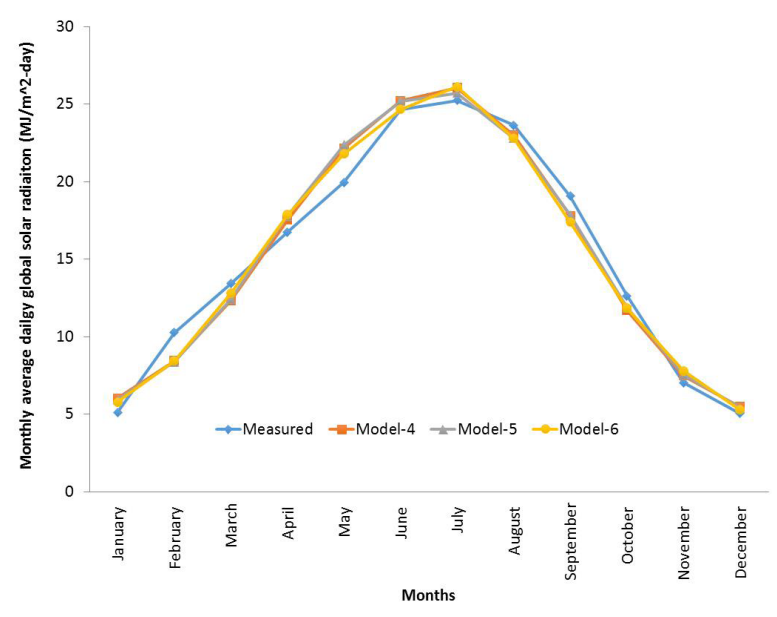

Figure 19. The annually distributions of the monthly average daily solar radiation estimated from Model-4, Model-5 and Model-6.

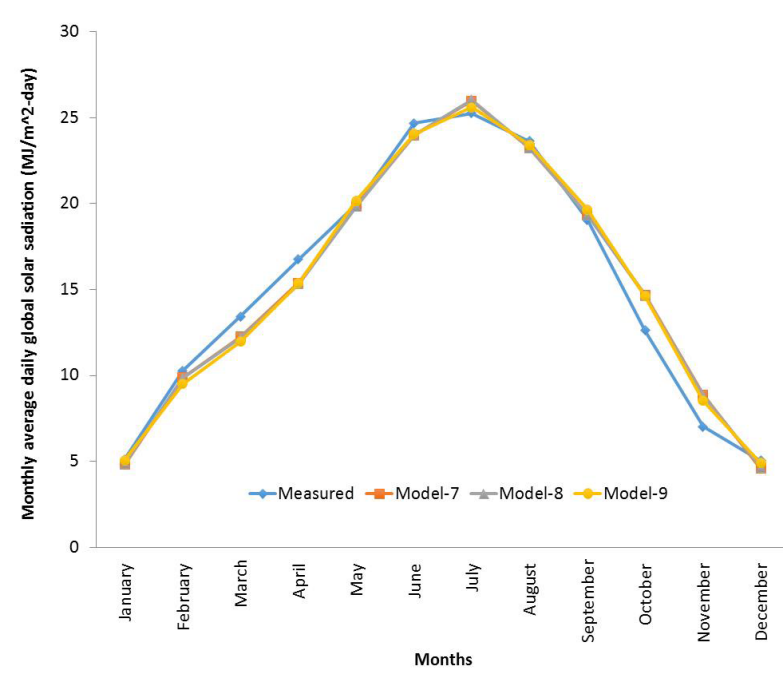

Figure 20. The annually distributions of the monthly average daily solar radiation estimated from Model-7, Model-8 and Model-9.

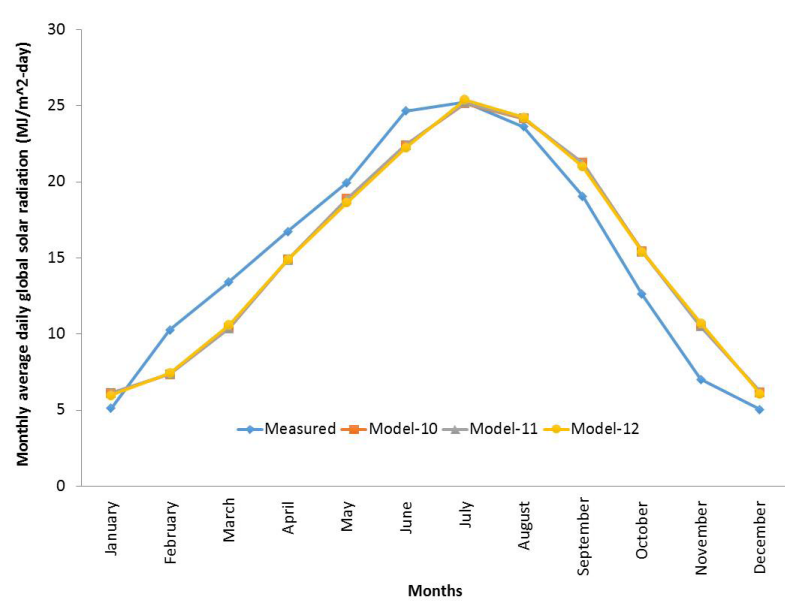

Figure 21. The annually distributions of the monthly average daily solar radiation estimated from Model-10, Model-11 and Model-12. 
Table 2. Measured and calculated metrological data for Eskisehir City.

\begin{tabular}{|c|c|c|c|c|c|c|c|c|c|c|}
\hline \multirow{2}{*}{ Months } & \multicolumn{6}{|c|}{ Measured values } & \multicolumn{4}{|c|}{ Calculated Values } \\
\hline & $\mathrm{H}$ & $\mathrm{S}$ & V & $\mathrm{T}$ & $\mathrm{P}$ & $\mathrm{RH}$ & Ho & So & $\mathrm{H} / \mathrm{Ho}$ & S/So \\
\hline January & 5.11 & 2.72 & 3.50 & 1.29 & 907.41 & 60.89 & 15.57 & 9.56 & 0.328 & 0.285 \\
\hline February & 10.27 & 4.75 & 3.58 & 2.73 & 902.91 & 53.48 & 20.87 & 10.55 & 0.492 & 0.450 \\
\hline March & 13.43 & 5.7 & 3.97 & 6.14 & 920.32 & 43.00 & 27.70 & 11.73 & 0.485 & 0.486 \\
\hline April & 16.75 & 6.95 & 4.05 & 11.24 & 907.68 & 42.56 & 34.77 & 13.05 & 0.482 & 0.533 \\
\hline May & 19.96 & 8.75 & 3.75 & 15.75 & 904.44 & 41.88 & 39.71 & 14.17 & 0.503 & 0.618 \\
\hline June & 24.66 & 10.4 & 4.02 & 19.73 & 910.98 & 39.77 & 41.71 & 14.74 & 0.591 & 0.706 \\
\hline July & 25.24 & 11.2 & 4.60 & 22.82 & 910.17 & 39.24 & 40.64 & 14.48 & 0.621 & 0.774 \\
\hline August & 23.63 & 10.1 & 4.39 & 21.73 & 911.33 & 40.18 & 36.61 & 13.51 & 0.645 & 0.747 \\
\hline September & 19.06 & 8.55 & 3.75 & 18.42 & 912.01 & 39.54 & 30.20 & 12.24 & 0.631 & 0.698 \\
\hline October & 12.62 & 6.68 & 3.37 & 11.87 & 912.84 & 47.14 & 22.83 & 10.93 & 0.553 & 0.611 \\
\hline November & 7.03 & 4.35 & 3.11 & 6.29 & 912.50 & 48.55 & 16.79 & 9.82 & 0.419 & 0.443 \\
\hline December & 5.05 & 2.63 & 3.58 & 1.39 & 910.69 & 50.78 & 14.12 & 9.27 & 0.357 & 0.284 \\
\hline Average & 15.23 & 6.90 & 3.81 & 11.62 & 910.27 & 45.58 & 28.46 & 12.00 & 0.509 & 0.553 \\
\hline
\end{tabular}

Table 3. The monthly average daily global solar radiation values estimated from the developed models.

\begin{tabular}{|c|c|c|c|c|c|c|c|c|c|c|c|c|c|}
\hline Months & Measured & Model-1 & Model-2 & Model-3 & Model-4 & Model-5 & Model-6 & Model-7 & Model-8 & Model-9 & Model-10 & Model-11 & Model-12 \\
\hline January & 5.11 & 5.41 & 5.39 & 5.36 & 6.03 & 5.93 & 5.78 & 4.81 & 4.87 & 5.06 & 6.10 & 6.13 & 5.98 \\
\hline February & 10.27 & 9.34 & 9.36 & 9.43 & 8.44 & 8.38 & 8.44 & 9.88 & 9.85 & 9.51 & 7.37 & 7.39 & 7.43 \\
\hline March & 13.43 & 12.98 & 13.01 & 13.07 & 12.31 & 12.41 & 12.80 & 12.25 & 12.20 & 11.96 & 10.39 & 10.37 & 10.59 \\
\hline April & 16.75 & 17.28 & 17.32 & 17.31 & 17.54 & 17.80 & 17.87 & 15.37 & 15.31 & 15.35 & 14.90 & 14.86 & 14.89 \\
\hline May & 19.96 & 21.76 & 21.80 & 21.63 & 22.14 & 22.36 & 21.80 & 19.86 & 19.82 & 20.17 & 18.89 & 18.86 & 18.65 \\
\hline June & 24.66 & 25.07 & 25.05 & 24.94 & 25.21 & 25.18 & 24.67 & 23.98 & 24.00 & 24.05 & 22.41 & 22.41 & 22.25 \\
\hline August & 23.63 & 22.92 & 22.88 & 22.92 & 22.99 & 22.80 & 22.79 & 23.23 & 23.24 & 23.41 & 24.18 & 24.21 & 24.25 \\
\hline September & 19.06 & 18.02 & 18.01 & 17.92 & 17.79 & 17.84 & 17.38 & 19.36 & 19.32 & 19.65 & 21.25 & 21.24 & 21.02 \\
\hline October & 12.62 & 12.42 & 12.44 & 12.35 & 11.69 & 11.86 & 11.85 & 14.69 & 14.63 & 14.61 & 15.46 & 15.41 & 15.40 \\
\hline November & 7.03 & 7.44 & 7.45 & 7.52 & 7.49 & 7.55 & 7.79 & 8.88 & 8.86 & 8.53 & 10.53 & 10.50 & 10.73 \\
\hline December & 5.05 & 4.90 & 4.88 & 4.85 & 5.48 & 5.40 & 5.28 & 4.58 & 4.65 & 4.90 & 6.19 & 6.23 & 6.09 \\
\hline Average & 15.23 & 15.30 & 15.30 & 15.29 & 15.26 & 15.27 & 15.22 & 15.24 & 15.23 & 15.23 & 15.23 & 15.23 & 15.22 \\
\hline
\end{tabular}

Table 4. The statistical analysis results of the new developed models

\begin{tabular}{|c|c|c|c|c|c|c|c|c|c|c|c|c|}
\hline \multirow[t]{2}{*}{ Months } & \multicolumn{12}{|c|}{ Relative Percentage Error (E) } \\
\hline & Model-1 & Model-2 & Model-3 & Model-4 & Model-5 & Model-6 & Model-7 & Model-8 & Model-9 & Model-10 & Model-11 & Model-12 \\
\hline January & 5.93 & 5.46 & 4.91 & 18.06 & 16.09 & 13.16 & -5.86 & -4.71 & -0.97 & 19.38 & 20.11 & 17.15 \\
\hline March & -3.33 & -3.08 & -2.65 & -8.32 & -7.60 & -4.65 & -8.80 & -9.17 & -10.92 & -22.64 & -22.80 & -21.15 \\
\hline April & 3.11 & 3.38 & 3.29 & 4.69 & 6.24 & 6.65 & -8.29 & -8.64 & -8.37 & -11.05 & -11.32 & -11.14 \\
\hline May & 9.01 & 9.19 & 8.38 & 10.93 & 12.00 & 9.23 & -0.51 & -0.69 & 1.04 & -5.37 & -5.54 & -6.58 \\
\hline June & 1.66 & 1.61 & 1.15 & 2.24 & 2.12 & 0.07 & -2.76 & -2.66 & -2.45 & -9.11 & -9.10 & -9.76 \\
\hline July & 3.33 & 3.06 & 3.83 & 3.18 & 1.84 & 3.52 & 2.90 & 3.17 & 1.45 & -0.38 & -0.19 & 0.65 \\
\hline August & -3.00 & -3.16 & -3.00 & -2.69 & -3.52 & -3.55 & -1.70 & -1.65 & -0.94 & 2.35 & 2.48 & 2.64 \\
\hline September & -5.49 & -5.51 & -6.01 & -6.68 & -6.40 & -8.85 & 1.56 & 1.35 & 3.11 & 11.50 & 11.44 & 10.28 \\
\hline October & -1.60 & -1.43 & -2.14 & -7.40 & -6.05 & -6.15 & 16.39 & 15.93 & 15.77 & 22.45 & 22.09 & 22.04 \\
\hline November & 5.80 & 6.03 & 6.98 & 6.61 & 7.49 & 10.91 & 26.30 & 26.08 & 21.35 & 49.80 & 49.47 & 52.63 \\
\hline December & -2.93 & -3.37 & -3.91 & 8.69 & 6.96 & 4.57 & -9.16 & -7.89 & -2.97 & 22.67 & 23.38 & 20.72 \\
\hline MAPE & 4.52 & 4.52 & 4.53 & 8.11 & 7.90 & 7.43 & 7.34 & 7.17 & 6.40 & 17.08 & 17.16 & 16.86 \\
\hline SSRE & 0.00265 & 0.00264 & 0.00257 & 0.00913 & 0.00868 & 0.00770 & 0.01051 & 0.01013 & 0.00815 & 0.04628 & 0.04643 & 0.04637 \\
\hline RSE & 0.01485 & 0.01482 & 0.01463 & 0.02759 & 0.02690 & 0.02532 & 0.02960 & 0.02906 & 0.02607 & 0.06210 & 0.06220 & 0.06216 \\
\hline MBE & 0.06611 & 0.06655 & 0.05849 & 0.02936 & 0.03310 & -0.01882 & 0.00311 & -0.00199 & -0.00006 & 0.00074 & 0.00022 & -0.00928 \\
\hline RMSE & 0.78383 & 0.78677 & 0.77312 & 1.12130 & 1.14694 & 1.09609 & 1.03032 & 1.02927 & 0.99493 & 2.13984 & 2.13959 & 2.13369 \\
\hline t-stat & 0.28073 & 0.28156 & 0.25163 & 0.08686 & 0.09576 & 0.05695 & 0.01000 & 0.00642 & 0.00021 & 0.00115 & 0.00034 & 0.01443 \\
\hline $\mathrm{R}^{2}$ & 0.99447 & 0.99439 & 0.99457 & 0.98835 & 0.98765 & 0.98845 & 0.98945 & 0.98948 & 0.99017 & 0.95368 & 0.95369 & 0.95395 \\
\hline
\end{tabular}




\section{CONCLUSIONS}

Solar energy occupies one of the most important places among the various possible alternative energy sources not only in Turkey but also in the other countries in the sunny belt. Solar energy technologies suggest a clean, renewable and domestic energy source, and are essential components of a sustainable energy future. In the design and study of solar energy, information on solar radiation and its components at a given location is very essential. In this regard, solar radiation models are of big importance.

The review and classification of the published works in estimation of solar radiation shows that sunshine duration, relative humidity, air temperature and geographical parameters such as longitude, altitude, and latitude are the most correlated parameters and the solar radiation estimation methods can be classified as linear, nonlinear, artificial intelligence modeling and fuzzy logic modelling techniques. In this study, twelve empirical models were developed to predict the monthly average daily global solar radiation over Eskişehir city of Turkey based on the measured data. The results of statistical analyzing methods indicate that all of the new developed empirical models are more suitable for Eskișehir City. However it is concluded that proposed Model-4 can be used to calculate the global solar radiation with good accuracy based on the statistical error tests. Model-4 is given as follows;

$$
\frac{H}{H_{o}}=0.0315+1.528 \frac{S}{S_{o}}-1.835\left(\frac{S}{S_{o}}\right)^{2}+1.144\left(\frac{S}{S_{o}}\right)^{3}
$$

Turkey lies in a sunny belt between $36^{\circ}$ and $42^{\circ} \mathrm{N}$ latitudes and is geographically well situated with respect to solar energy potential. If the information of solar radiation potential is very limited, the temperature based models are an essential and economical tool for estimating solar radiation. In this regard, the solar radiation potential can be easily estimated from Model-10/-11/-12 for Eskișehir and neighboring cities in the similar region and climate. Model-11 is statistically best temperature based model and given as follows;

$$
H=5.018+0.8669 T+0.00076 T^{2}
$$

\section{NOMENCLATURE}
$a, b, c, d$ coefficients in empirical relationship(-)
$c_{a} \quad$ average of calculated value
$c_{i} \quad i^{\prime}$ th calculated value
$E \quad$ relative percentage error (\%)
$G_{a} \quad$ extraterrestrial radiation $\left(\frac{W}{m^{2}}\right)$
$G_{x} \quad$ solar constant $\left(=1367 \frac{\mathrm{W}}{\mathrm{m}^{2}}\right)$
$H \quad$ monthly average daily global solar radiation $\left(\frac{M}{m^{2}-d a y}\right)$
$H_{o} \quad$ monthly average daily extraterrestrial solar radiation $\left(\frac{M}{m^{2}-d a y}\right)$
$m_{a} \quad$ average of measured value
$m_{i} \quad i$ th measured value

$\begin{array}{ll}M B E & \text { mean bias error }\left(\frac{M}{m^{2}-d a y}\right) \\ M P E & \text { mean percentage error (\%) } \\ M A P E & \text { mean absolute percentage error (\%) } \\ n_{\text {day }} & \text { number of days of the year starting from fist January } \\ R^{2} & \text { correlation coefficient (per \%) } \\ R M S E & \text { root mean square error }\left(\frac{M}{m^{2}-d a y}\right) \\ R S E & \text { relative standard error (\%) } \\ S & \text { day length (h) } \\ S_{o} & \text { daylight (bright sunshine) duration (h) } \\ S S R E & \text { sum of squares of relative errors (\%) } \\ t-\text { stat } & \text { t-statistic (-) }\end{array}$

Z altitude (elevation) (m)

\section{Greek letters}

$\begin{array}{ll}\delta & \text { solar declination angle }\left({ }^{0}\right) \\ \phi & \text { latitude of site }\left({ }^{0}\right)\end{array}$

\section{REFERENCES}

[1] Teke, A., Yıldırım, H.B., Celik, O., (2015). Evaluation and performance comparison of different models for the estimation of solar radiation. Renewable and Sustainable Energy Reviews. 50:1097-1107. https://doi.org/10.1016/j.rser.2015.05.049

[2] Behar, O., Khellaf, A., Mohammedi, K., (2015). Comparison of solar radiation models and their validation under Algerian climate-The case of direct irradiance. Energy Conversion and Management. 98:236-251. https://doi.org/10.1016/j.enconman.2015.03.067

[3] Gueymard, C.A., (2014). A review of validation methodologies and statistical performance indicators for modeled solar radiation data: Towards a better bankability of solar projects. Renewable and Sustainable Energy Reviews. 39:1024-34. https://doi.org/10.1016/j. rser.2014.07.117

[4] Gueymard, C.A., (2009). Direct and indirect uncertainties in the prediction of tilted irradiance for solar engineering applications. Solar Energy. 83:432-444. https://doi.org/10.1016/j.solener.2008.11.004

[5] Ulgen, K., Hepbasli, A., (2009). Diffuse solar radiation estimation models for Turkey's big cities. Energy Conversion and Management. 50: 149-156. https://doi.org/10.1016/j.enconman.2008.08.013

[6] Khorasanizadeh, H., Mohammadi, K., (2013). Introducing the best model for predicting the monthly mean global solar radiation over six major cities of Iran. Energy. 51:257-266. https://doi.org/10.1016/j. energy.2012.11.007

[7] Yaiche, M.R., Bouhanik, A., Bekkouche, S.M.A., Malek, A., Benouaz, T., (2014). Revised solar maps of Algeria based on sunshine duration. Energy Conversion Management. 82:114-123. https://doi. org/10.1016/j.enconman.2014.02.063

[8] Robaa, S.M., (2009). Validation of the existing models for estimating global solar radiation over Egypt. Energy Conversion and Management. 50:184-193. https://doi.org/10.1016/j.enconman.2008.07.005 
[9] Manzano, A., Martin, M.L., Valeroa, F., Armenta, C., (2015). A single method to estimate the daily global solar radiation from monthly data. Atmospheric Research. 166:70-82. https://doi.org/10.1016/j. atmosres.2015.06.017

[10] Yao, W., Li, Z., Xiu, T., Lu, Y., Li, X., (2015). New decomposition models to estimate hourly global solar radiation from the daily value. Solar Energy. 120: 87-99. https://doi.org/10.1016/j.solener.2015.05.038

[11] Mesri, M., (2015). Numerical methods to calculate solar radiation, validation through a new Graphic User Interface design. Energy Conversion and Management. 90: 436-445. https://doi. org/10.1016/j.enconman.2014.11.037

[12] Mohammadi, K., Shamshirband, S., Tong, C.W., Alam, K.A., Petkovic, D., (2015). Potential of adaptive neuro-fuzzy system for prediction of daily global solar radiation by day of the year. Energy Conversion and Management. 93: 406-413. https://doi.org/10.1016/j. enconman.2015.01.021

[13] Linares-Rodríguez, A., Ruiz-Arias, J.A., Pozo-Vázquez, D., Tovar-Pescador, J., (2011). Generation of synthetic daily global solar radiation data based on ERA-Interim reanalysis and artificial neural networks. Energy. 36: 5356-5365. https://doi.org/10.1016/j.energy.2011.06.044

[14] Benghanem, M., Mellit, A., Alamri, S.N., (2009). ANN-based modelling and estimation of daily global solar radiation data: A case study. Energy Conversion and Management. 50: 1644-1655. https://doi. org/10.1016/j.enconman.2009.03.035

[15] Sahin, M., Kaya, Y., Uyar, M., (2013). Comparison of ANN and MLR models for estimating solar radiation in Turkey using NOAA/ AVHRR data. Advances in Space Research. 5:891-904. https://doi. org/10.1016/j.asr.2012.10.010

[16] Koca, A., Oztop, H.F., Varol, Y., Koca, G.O., (2011). Estimation of solar radiation using artificial neural networks with different input parameters for Mediterranean region of Anatolia in Turkey. Expert Systems with Applications. 38: 8756-8762. https://doi.org/10.1016/j. eswa.2011.01.085

[17] Qazi, A., Fayaz, H., Wadi, A., Raj, R.G., Rahim, N.A., Khan, W.A., (2015). The artificial neural network for solar radiation prediction and designing solar systems: a systematic literature review. Journal of Cleaner Production. 104:1-12. https://doi.org/10.1016/j.jclepro.2015.04.041

[18] Park, J.K., Das, A., Park, J.H., (2015). A new approach to estimate the spatial distribution of solar radiation using topographic factor and sunshine duration in South Korea. Energy Conversion and Management. 101: 30-39. https://doi.org/10.1016/j.enconman.2015.04.021

[19] Hassan, G.E., Youssef, M.E., Mohamed, Z.E., Ali, M.A., Hanafy, A.A., (2016). New temperature-based models for predicting global solar radiation. Applied Energy. 179: 437-450. https://doi.org/10.1016/j. apenergy.2016.07.006

[20] Yıldızay, H.D., (2015). Eskişehir ve yöresinde enerji üretimi amaçı güneş ışınımı ve rüzgar hızı değerlerinin tespiti ve kullanılabilirliğini analizi. Determination of solar radiation and wind speed values for energy generation and availability analysis in Eskisehir region. Doctoral Thesis. Eskişehir Osmangazi Üniversitesi.

[21] Zang, H., Cheng, L., Ding, T., Cheung, K.W., Wang, M., Wei, Z., Sun, G., (2019). Estimation and validation of daily global solar radiation by day of the year-based models for different climates in China. Renewable Energy. 135: 984-1003. https://doi.org/10.1016/j. renene.2018.12.065

[22] Jamil, B., Siddiqui, A.T., (2017). Generalized models for estimating of diffuse solar radiation based on clearness index and sunshine duration in India: Applicability under different climatic zones. Journal of Atmospheric and Solar-Terrestrial Physics. 157-158:16-34. https:// doi.org/10.1016/j.jastp.2017.03.013

[23] Behar, O., Khellaf, A., Mohammedi, K., (2015). Comparison of solar radiation models and their validation under Algerian climate- The case of direct irradiance. Energy Conversion and Management. 98: 236-251. https://doi.org/10.1016/j.enconman.2015.03.067

[24] Duffie, J.A., Beckman, W.A., (2006). Solar engineering of thermal processes. 3rd ed. New York: John Wiley \& Son.

[25] Angstrom, A., (1924). Solar and Terrestrial Radiation Report to the International Commission for Solar Research on Actinometric Investigations of Solar and Atmospheric Radiation. Q. J. R. Meteorol. Soc.,50: 121-126.

[26] Prescott, J.A., (1940). Evaporation from water surface in relation to solar radiation. Trans Roy Soc Austr. 46:114-118.

[27] Page, J.K., (1961). The estimation of monthly mean values of daily total short wave radiation on vertical and inclined surface from sunshine records for latitudes $40 \mathrm{~N}-40 \mathrm{~S}$. Proceedings of UN Conference on New Sources of Energy. 4: 378-390.

[28] Chang, K., Zhang, Q., (2019). Improvement of the hourly global solar model and solar radiation for air-conditioning design in China. Renewable Energy. 138: 1232-1238. https://doi.org/10.1016/j. renene.2019.02.069

[29] Tarhan, S., Sari, A., (2005). Model selection for global and diffuse radiation over the Central Black Sea (CBS) region of Turkey. Energy Conversion and Management. 46(4): 605-613. https://doi. org/10.1016/j.enconman.2004.04.004

[30] Bakirci, K., (2009). Correlations for estimation of daily global solar radiation with hours of bright sunshine in Turkey. Energy. 34:485501. https://doi.org/10.1016/j.energy.2009.02.005

[31] Katiyar, A.K., Pandey, C.K., (2010). Simple correlation for estimating the global solar radiation on horizontal surfaces in India. Energy. 35:5043-5048. https://doi.org/10.1016/j.energy.2010.08.014

[32] Li, H., Ma, W., Lian, Y., Wang, X., Zhao, L., (2011). Global solar radiation estimation with sunshine duration in Tibet. China. Renewable Energy. 36:3141-3145. https://doi.org/10.1016/j.renene.2011.03.019

[33] Behrang, M.A., Assareh, E., Noghrehabadi, A.R., Ghanbarzadeh, A., (2011). New sunshine-based models for predicting global solar radiation using PSO (particle swarm optimization) technique. Energy. 36:3036-3049. https://doi.org/10.1016/j.energy.2011.02.048

[34] Duzen, H., Aydin, H., (2012). Sunshine-based estimation of global solar radiation on horizontal surface at Lake Van region (Turkey). Energy Conversion and Management. 58: 35-46. https://doi. org/10.1016/j.enconman.2011.11.028

[35] Teke, A., Yıldırım, H.B., (2014). Estimating the monthly global solar radiation for Eastern Mediterranean Region. Energy Conversion and Management. 87:628-635. https://doi.org/10.1016/j.enconman.2014.07.052

[36] Chelbi, M., Gagnon, Y., Waewsak, J., (2015). Solar radiation mapping using sunshine duration based models and interpolation techniques: application to Tunisia. Energy Conversion and Management. 101: 203-215. https://doi.org/10.1016/j.enconman.2015.04.052

[37] Dincer, I., Dilmac, S., Ture, I.E., Edin M., (1996). A simple technique for estimating solar radiation parameters and its application for Gebze. Energy Conversion and Management. 37 (2):183-198. https://doi. org/10.1016/0196-8904(95)00168-D

[38] Dumas, A., Andrisani, A., Bonnici, M., Graditi, G., Leanza, G., Madonia, M., Trancossi, M., (2015). A new correlation between global solar energy radiation and daily temperature variations. Solar Energy. 116: 
117-124. https://doi.org/10.1016/j.solener.2015.04.002

[39] Trabea, A.A., Shaltout, M.A.M., (2000). Correlation of global solar radiation with meteorological parameters over Egypt. Renewable Energy. 21:297-308. https://doi.org/10.1016/S0960-1481(99)00127-5

[40] Annandale, J., Jovanovic, N., Benadé, N., Allen, R., (2002). Software for missing data error analysis of Penman-Monteith reference evapotranspiration. Irrigation Science. 21:57-67. https://doi.org/10.1007/ s002710100047

[41] Allen, R.G., (1997). Self-calibrating method for estimating solar radiation from air temperature. J Hydrolic Engineering. 2(2):56-67. https://doi.org/10.1061/(ASCE)1084-0699(1997)2:2(56)

[42] Goodin, D., Hutchinson, J., Vanderlip, R.L., Knapp, M.C., (1999). Estimating solar irradiance for crop modeling using daily air temperature data. Acronomy Journal. 91(5): 845-851. https://doi. org/10.2134/agronj1999.915845x

[43] Tapakis, R., Michaelides, S., Charalambides, A.G., (2016). Computations of diffuse fraction of global irradiance: Part 1- Analytical modelling. Solar Energy. 139:711-722. https://doi.org/10.1016/j.solener.2014.10.005

[44] Kurtz, B., Kleissl, J. (2017). Measuring diffuse, direct, and global irradiance using a sky imager. Energy. 141: 311-322. https://doi. org/10.1016/j.solener.2016.11.032

[45] Mghouchi, Y.E., Bouardi, A.E., Choulli, Z., Ajzoul, T., (2016). Models for obtaining the Daily direct, diffuse and global solar radiations. Renewable and Sustainable Energy Reviews. 56: 87-99. https://doi. org/10.1016/j.rser.2015.11.044

[46] Yorukoglu, M., Celik, A.N., (2006). A critical review on the estimation of daily global solar radiation from sunshine duration. Energy Conversion and Management. 47 (15):2441-2450. https://doi. org/10.1016/j.enconman.2005.11.002 